\title{
Pengaruh Dimensi Orientasi Kewirausahaan dan Jaringan Usaha terhadap Kinerja Usaha UKM di Jakarta Barat
}

\author{
Andy Hendrawan dan Andi Wijaya \\ Program Studi Manajemen Fakultas Ekonomi \& Bisnis \\ Universitas Tarumanagara \\ Email: andyandy57@yahoo.com
}

\begin{abstract}
The purpose of this study was to determine and analyze the effect of innovation, proactivity, business network risk taking on the performance of SME businesses in West Jakarta. Sampling of this research was conducted by judgment sampling method. Researchers distributed questionnaires to 100 business owners in West Jakarta. Data analysis using SEM PLS analysis. The results of the analysis concluded that innovation, proactive, risk taking and business networks influence the performance business of SME in West Jakarta
\end{abstract}

Keywords: Innovation, proactive, risk taking, business network, performance

\begin{abstract}
Abstrak: Tujuan penelitian ini adalah untuk mengetahui dan menganalisa pengaruh inovasi, proaktif, pengambilan risiko jaringan usaha terhadap kinerja usaha UKM di Jakarta Barat. Pengambilan sampel penelitian ini dilakukan dengan metode judgement sampling. Peneliti menyebarkan kuesioner kepada 100 pemilik usaha di Jakarta Barat. Analsis data menggunakan analisis SEM PLS. Hasil analisis menyimpulkan bahwa inovasi, proaktif, pengambilan risiko dan jaringan usaha berpengaruh terhadap kinerja usaha UKM di Jakarta Barat
\end{abstract}

Kata kunci: Inovasi, proaktif, pengambilan risiko, jaringan usaha, kinerja

\section{LATAR BELAKANG}

Kinerja UKM menjadi penting untuk dibicarakan karena menyangkut keberadaan dan keberlangsungan usahanya dimasa yang akan datang. Tanpa adanya kinerja usaha, maka UKM yang selama ini dijalankan berarti dianggap tidak mampu memberikan kontribusi yang menguntungkan bagi pengelola dan orang lain yang ikut terlibat didalammya. Kinerja usaha merupakan salah satu ukuran prestasi dari sebuah usaha yang didapatkan melalui aktifitas produksi dan pemasaran secara keseluruhan yang berasal dari organisasi bisnis. Kinerja usaha dapat dipandang sebagai sebuah konsep yang digunakan dalam mengukur sampai dimana prestasi pasar yang telah dicapai oleh suatu produk yang dihasilkan organisasi bisnis. Kinerja Usaha Kecil dan Menengah dapat diartikan sebagai ukuran tercapainya sebuah usaha yang dijalankan oleh seseorang atau kelompok yang mengelola unit usaha berdasarkan target atau standar yang telah ditentukan sebelumnya, dimana usaha tersebut masuk dalam kategori Usaha Kecil dan Menengah (UKM). Kinerja UKM ini menjadi hal yang sangat penting untuk diperhatikan oleh semua kalangan. Pembinaan dan pelatihan dalam rangka mencapai peningkatan dan pertumbuhan kinerja usaha UKM yang berkesinambungan menjadi prioritas bagi pemerintah melalui dinas terkait agar UKM ini tetap eksis ditengah persaingan ekonomi global. Soedjono (2005), kinerja organisasi atau kinerja perusahaan merupakan indikator tingkatan prestasi yang dapat dicapai dan mencerminkan keberhasilan manajer atau pengusaha. Zimmerer (2008: 57) menjelaskan bahwa kinerja usaha adalah sebuah hasil yang 
dicapai dari kemampuan untuk mengembangkan ide-ide baru dan untuk menemukan caracara baru dalam melihat masalah dan peluang dan kemampuan untuk menerapkan solusi kreatif terhadap masalah dan peluang untuk meningkatkan atau untuk memperkaya kehidupan orang-orang.

Pada dasarnya, ada banyak faktor yang dapat mempengaruhi kinerja usaha. Faktor-faktor yang dapat mempengaruhi kinerja usaha tersebut antara lain adalah orientasi kewirausahaan yang terdiri dari inovasi, proaktif dan pengambilan risiko serta jaringan usaha (Yoon, et al. 2018). Inovatif adalah kecenderungan perusahaan untuk menggunakan dan mendukung ideide baru, eksperimen, dan proses kreatif yang mungkin berhasil dalam memperkenalkan produk atau jasa baru, hal-hal baru atau proses teknologi. Inovasi dianggap sebagai sebuah penyedia solusi untuk permasalahan yang rutin atau baru. Proaktif dianggap sebagai meramalkan sesuatu yang belum terjadi dan mengambil tindakan untuk masalah yang mereka pikir mungkin akan terjadi di masa depan. Keberanian mengambil risiko dipahami untuk memasuki di dalam bidang usaha yang tak terlihat atau baru.

Menurut Hendriyanto (2015) faktor yang mempengaruhi kinerja usaha adalah jaringan usaha. Jaringan usaha dapat diartikan sebagai suatu bentuk organisasi di bidang ekonomi yang dimanfaatkan untuk mengatur koordinasi serta mewujudkan kerjasama antar unsur dalam organisasi. Unsur-unsur tersebut pada umumnya berupa unit usaha, dapat juga berupa non unit usaha, tetapi merupakan unsure dalam rangkaian yang memfasilitasi penyelenggaraan unit usaha. Organisasi yang dimaksud dapat bersifat formal maupun informal. Menghasilkan produk atau jasa dan membuat produk atau jasa itu tersedia bagi pembeli memerlukan pembangunan hubungan yang bukan hanya dengan pelanggan tetapi juga dengan pemasok kunci dan penjual perantara dalam rantai pasokan perusahaan (Kotler dan Amstrong, 2008). Jaringan usaha melibatkan unit usaha lain dalam kegiatan usaha yang dilakukan oleh produsen, baik dalam kegiatan produksi maupun pemasaran produk. Produsen menggunakan perantara karena mereka menciptakan efisiensi yang lebih besar dalam menyediakan barang bagi pasar sasaran. Melalui kontak, pengalaman, spesialisasi dan skala operasi, perantara biasanya menawarkan perusahaan lebih dari apa yang dapat dicapai perusahaan sendiri (Kotler dan Amstrong, 2008). Kinerja Usaha dapat meningkat dengan memperluas jejaring usaha.

\section{KAJIAN TEORI}

Teori yang mendasari penelitian ini adalah teori Resource - Based View atau dikenal dengan RBV. Menurut Barney (1991) sukses tidaknya sebuah perusahaan akan ditentukan oleh kekuatan dan kelemahan yang ada dalam internal perusahaan bukan pada eksternal perusahaan. Agar menjadi sumber daya potensial dalam Sustained Competitive Advantage, maka sumber daya perusahaan harus memiliki empat artribut, yaitu : (a) bernilai (valuable resources), (b) langka (rare resources), (c) tidak dapat ditiru (imperfectly imitable resources), (d) tidak ada sumber daya pengganti (non-substitutability resources). Asumsi dasar teori RBV adalah bahwa sumber daya pada sebuah perusahaan bergabung mnejadi satu (bundles) dan kemampuan yang mendasari produksi tidak sama satu dengan yang lainnya. Asumsi pertama; adanya heterogenitas sumber daya dalam perusahaan, dan kedua; beberapa sumber daya yang ada dalam perusahaan bersifat sulit untuk ditiru atau tidak elastik pada pasokannya. Heterogenitas sumber daya perusahaan memiliki arti bahwa tidak mungkin dalam perusahaan mampu memiliki sumber daya yang persis sama dengan perusahaan lainnya yang disebabkan oleh adanya kemampuan perusahaan yang saling berbeda - beda. Sedangkan beberapa sumber daya yang ada dalam perusahaan bersifat sulit untuk ditiru oleh pesaingnya terutama dalam masalah pada sumber daya manusianya, dengan kata lain keberhasilan sebuah perusahaan ditentukan oleh sumber daya yang dimilikinya dan 
kapabilitas perusahaan yang mampu merubah sumber daya tersebut menjadi sebuah perusahaan yang bermanfaat pada ekonomi (economic benefit)

Inovasi. merupakan komersialisasi dari ide mengenai produk atau proses baru (Sari, 2012: 3). Inovatif merupakan cara untuk terus membangun dan mengembangkan organisasi yang dapat dicapai melalui introduksi teknologi baru, aplikasi baru dalam produk dan pelayanan, pengembangan pasar baru dan memperkenalkan bentuk-bentuk baru organisasi (Widodo, 2013: 205).

Proaktif. Menurut Hapsari dan Setiawan (2019:49) proaktif adalah: "Proktif adalah sikap pemilik usaha yang mencari peluang baru untuk mengembangkan, memperkenalkan, dan membuat perbaikan pada produk maupun jasa". Sedangkan Widodo (2013: 209) mendefinisikan proaktif "sebagai kemampuan dinamis untuk beradaptasi terhadap lingkungan". Kreiser, Marino, dan Weaver (2015) menyatakan bahwa proactive adalah tindakan yang merupakan inisiatif seseorang dalam menyelesaikan masalah.

Pengambilan resiko. menurut Haryo dan Yengky (2014: 13) adalah keberanian untuk membuat keputusan besar dan komitmen yang beresiko dimana memiliki kesempatan kegagalan yang berharga. Menurut Jackson dalam dalam Karimi, et.al (2011:3) pengambilan risiko adalah: "Risk propensity can be defined as a personality trait involving the willingness to pursue decisions or courses of action involving uncertainty regarding success or failure outcomes."

Jaringan usaha. Menurut Enny dan Guruh, (2013). Jaringan usaha adalah kemampuan ikatan jejaring (networkties) menghubungkan para pelaku dengan berbagai usaha misal partner usaha, teman, agen, mentor untuk mendapatkan sumber daya yang dibutuhkan misalnya informasi, uang, dukungan moral para pelaku jejaring. Menurut Lestari, dkk (2015:4) jaringan usaha adalah "segala hubungan yang membantu dalam pembentukan sebuah usaha baru sebagai bagian dari jaringan”.

Kinerja. Menurut Edison (2016:58) "kinerja adalah hasil dari suatu proses yang mengacu dan diukur selama periode waktu tertnetu berdasarkan ketentuan atau kesepakatan yang ditelah ditetapkan sebelumnya". Kinerja adalah istilah umum yang digunakan untuk menunjukkan sebagian atau seluruh tindakan atau aktivitas dari suatu organisasi pada suatu periode (Mulyadi, 2010:78). Menurut Nurlaila (2010:71), "kinerja merupakan hasil atau keluaran dari suatu proses".

Kaitan Inovasi terhadap Kinerja Usaha. Inovasi adalah salah satu instrumen dasar pertumbuhan strategies untuk masuk pasar baru, meningkatkan pangsa pasar yang ada dan untuk menyediaan perusahaan dengan keunggulan kompetitif. Termotivasi oleh meningkatnya persaingan di pasar global, perusahaan sudah mulai memahami pentingnya inovasi, karena teknologi cepat berubah dan persaingan global yang parah dengan cepat mengikis nilai tambah produk dan jasa yang ada. Dengan demikian, inovasi merupakan komponen yang tak terpisahkan dari strategi perusahaan selama beberapa alasan seperti untuk menerapkan proses manufaktur yang lebih produktif, untuk tampil lebih baik di pasar, untuk mencari reputasi positif dalam persepsi pelanggan dan sebagai hasilnya untuk mendapatkan keunggulan kompetitif yang berkelanjutan. Inovasi memberikan perusahaan sebuah orientasi strategis untuk mengatasi masalah yang dihadapi perusahaan oleh karena itu semakin baik inovasi maka semakin tinggi tingkat kesuksesan bisnis (Gunday et al., 2009). 
Dalam penelitian yang dilakukan Hendriyanto (2015) menyatakan bahwa inovasi berpengaruh signifikan terhadap kinerja usaha. Inovasi secara luas dianggap sebagai salah satu sumber terpenting dari keunggulan kompetitif berkelanjutan dalam lingkungan yang semakin berubah, karena mengarah pada peningkatan produk dan proses, membuat kemajuan berkelanjutan yang membantu perusahaan untuk bertahan hidup, memungkinkan perusahaan tumbuh lebih cepat, lebih efisien, dan pada akhirnya menjadi lebih menguntungkan daripada non-inovator. Kemudian dalam penelitian Yoon, et al (2018) juga menyimpulkan bahwa inovasi berpengaruh terhadap kinerja usaha. Mereka menemukan bahwa kecenderungan perusahaan terhadap inovasi adalah sangat penting dalam lingkungan kompetitif untuk mendapatkan keunggulan kompetitif yang lebih tinggi.

Kaitan Proaktif Terhadap Kinerja Usaha. Perilaku proaktif sebagai upaya mengambil inisiatif dalam meningkatkan ide dan kreativitas-kreativitas baru mengubah status quo dibanding hanya bertindak pasif dalam menghadapi kondisi saat ini. Dari pemahaman ini dapat diasumsikan bahwa individu yang memiliki kepribadian proaktif memiliki kesempatan dan tindakan untuk menunjukkan dirinya kepada orang lain dalam bentuk seperti memperlihatkan inisiatif, bertindak cepat, menentang status quo, suka bekerja keras dan gigih ketika mereka ingin mengadakan perubahan yang berarti. Semakin proaktif sifat pengusaha maka semakin sukses bisnis yang dikelolanya (Yuni, 2011).

Penelitian yang dilakukan Yoon, et al (2018) menyimpulkanbahwa perilaku proaktif seorang pengusaha akan meningkatkan kinerja usaha yang di jalankannya. Demikian juga dengan penelitianyang dilakukan Arshad, et al (2014) menyatakan bahwa proaktif berpengaruh signifikan terhadap kinerja usaha. Peran dari sikap proaktif diantaranya seperti aktif dalam melakukan promosi untuk memasarkan produk, dapat menyusun strategi agar keuntungan dan output produk yang dipasarkan memenuhi target. Kecenderungan dalam menjalankan usahanya dengan mengambil sikap terhadap suatu masalah, yaitu bila masalah yang muncul akan disikapi, bukan untuk dihindari.

Kaitan Pengambilan Risiko terhadap Kinerja Usaha. Untuk mencapai sebuah kesuksesan tentu saja ada risiko yang harus dihadapi. Begitu juga dengan berwirausaha, ketika seseorang memutuskan untuk berwirausaha maka harus siap terhadap risiko yang akan dihadapi. Hal ini menunjukkan bahwa semakin mendekati puncak kesuksesan maka semakin besar pula risiko yang harus dihadapi. Wirausaha yang tidak takut terhadap risiko maka semakin besar pula kesuksesan yang akan didapat. Seorang wirausaha harus berani menghadapi risiko. Semakin besar risiko yang dihadapinya, semakin besar pula kesempatan untuk meraih keuntungan. Wirausaha yang sukses dinilai dari keinginannya untuk mulai bermimpi dan berani menanggung risiko dalam upaya mewujudkannya (Suryana, 2006). Seorang entrepreneur harus mampu mengambil risiko. Kemauan dan kemampuan untuk mengambil risiko merupakan salah satu nilai utama dalam berwirausaha. Entrepreneur yang tidak mau mengambil risiko akan sukar memulai atau berinisiatif. Seorang wirausaha pasti selalu dihadapkan pada risiko dan ketidakjelasan (Ida, 2015). Dalam penelitian yang dilakukan Yoon, et al (2018) menyatakan bahwa kecenderungan mengambil risiko berpengaruh signifikan terhadap kinerja usaha. Demikian juga dengan penelitian yang dilakukan oleh Arshad, et al (2014) serta penelitian Hapsari dan Setiawan (2019) menyimpulkan bahwa kecenderungan mengambil risiko berpengaruh terhadap kinerja usaha.

Kaitan Jaringan Usaha terhadap Kinerja Usaha. Jaringan usaha merupakan modal sosial yang di perlukan bagi para pelaku usaha ataupun pemilik usaha. Modal sosial yang diterapkan oleh para pelaku usaha UMKM sangat berpengaruh terhadap keberlangsungan usaha. Jaringan usaha berkontribusi untuk tujuan entrepreneurial pengusaha. Jaringan usaha 
memilki beberapa kegunaan untuk para pengusaha.Kegunaan pertama ialah seberapa besar jaringan. Pengusaha dapat memperluas jaringan utnuk mendapatkan informasi penting sebaik-baiknya. Hal tersebut mempengaruhi kinerja usaha untuk pengembangan bisnis di masa yang akan dating dengan memanfaatkan informasi yang didapat dari networking yang dimiliki pemilik..

Pada penelitian Yoon et, al (2018), menyatakan bahwa jaringan usaha berpengaruh positif terhadap Kinerja usaha. Hasil ini memberi makna bahwa informasi dan pengetahuan mempercepat pemahaman yang lebih baik mengenai pengembangan hubungan yang kuat dan flexibel dengan para pelanggan, dan juga dengan anggota-anggota rantai pemasok yang lain. Hubungan yang lebih dekat dengan pemasok akan memberikan kontribusi yang cukup kuat terhadap kinerja perusahaan, antara lain efisiensi biaya, peningkatan kualitas, reliabilitas, dan pemenuhan kebutuhan input yang selalu tersedia setiap saat. Selain itu pemasok dapat meningkatkan sumber informasi tentang pengembangan pasar, teknologi baru, pergerakan para pesaing.

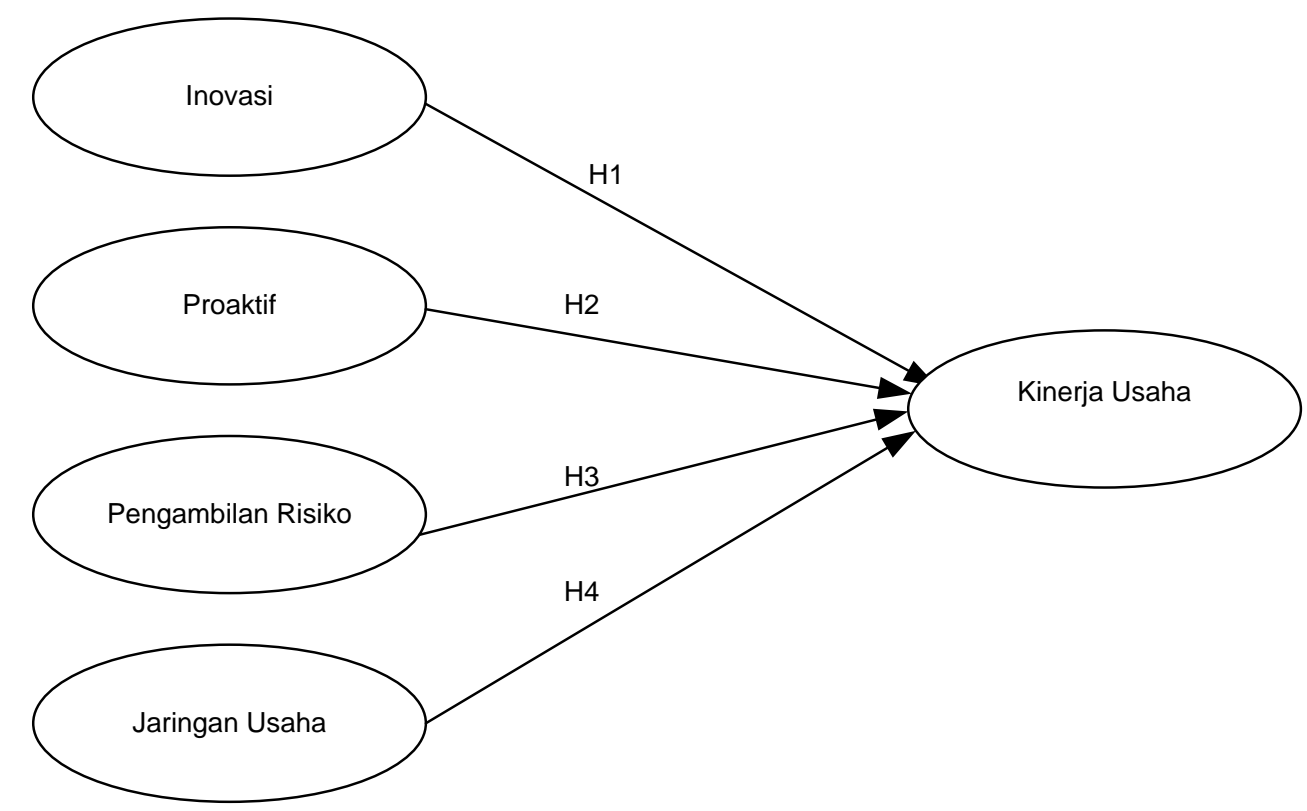

Gambar 1. Kerangka Pemikiran berikut:

Berdasarkan kerangka pemikiran diatas maka hipotesis penelitian ini adalah sebagai

H1: Terdapat pengaruh positif signifikan inovasi terhadap kinerja usaha UKM di Jakarta Barat.

H2: Terdapat pengaruh positif signifikan proaktif terhadap kinerja usaha pada UKM di Jakarta Barat

H3: Terdapat pengaruh positif signifikan pengambilan risiko terhadap kinerja usaha pada UKM di Jakarta Barat

H4: Terdapat pengaruh positif signifikan jaringan usaha terhadap kinerja usaha pada UKM di Jakarta Barat

\section{METODOLOGI}

Penelitian ini menggunakan disain penelitian kausal yang bertujuan membuat deskriptif secara sistematis, faktual, dan akurat mengenai fakta-fakta dan sifat-sifat dari populasi. 
Melalui penerapan metode kausal diharapkan peneliti mendapatkan informasi yang tepat dan akurat serta gambaran dari pengaruh inovasi (X1), proaktif (X2), pengambilan risiko (X3), jaringan usaha (X4) terhadap kinerja usaha (Y) pada UKM yang berada di wilayah Jakarta Barat. Populasi adalah seluruh UKM yang berada di wilayah Jakarta Barat. Jumlah responden yang digunakan adalah 100 orang yang merupakan pemilik Usaha Kecil Menengah

Data dianalisis menggunakan PLS-SEM dimana data diolah dengan program software SmartPLS 3. Pertama, pengolahan dilakukan pada outer model untuk menguji validitas (konvergen dan diskriminan) dan reliabilitas. Uji validitas konvergen dilihat dari nilai outer loadings di antara 0,5-0,7 kemudian AVE > 0,5. Selanjutnya untuk uji validitas diskriminan, beracuan pada Fornell-Larcker Criterion dan Cross Loadings . Kemudian pada analisis reliabilitas, beracuan pada nilai cronbach's alpha dan composite reliability $>0,7$.

Kedua, pengolahan dilakukan pada inner model untuk menguji hipotesis yang telah dihasilkan. Sebelum pengujian hipotesis, pertama dilakukan pengujian hubungan antar konstruk dengan melihat nilai $\mathrm{R}$-square $\left(\mathrm{R}^{2}\right)$ dengan kriteria $(1-0,75)$ "bersifat kuat", $(0,74$ - 0,5) "bersifat moderat", dan $(0,49-0,25)$ "bersifat lemah" (Ghozali dan Latan, 2015:78), nilai $\mathrm{Q}$-square $\left(\mathrm{Q}^{2}\right)$ dengan kriteria $\mathrm{Q}^{2}>0$ "memiliki kemampuan prediksi" (Chin, 2010), dan nilai GoF (Goodness of Fit) dengan kriteria 0,1 "kelayakan model kecil", 0,25 "kelayakan model sedang", dan 0,36 "kelayakan model besar" (Tenenhaus, 2005). Selanjutnya pengujian hipotesis, untuk melihat pengaruh yang terjadi lihat (positif/ negatif) dari coefficient yang dihasilkan, dan menggunakan $t$-statistics $>1,645$ (hipotesis tidak ditolak) dan $p$-values $<0,05$ (hipotesis signifikan).

\section{HASIL UJI STATISTIK}

\section{Hasil Uji validitas}

Pada hasil validitas konvergen, didapatkan semua angka $>0,5$ pada nilai outer loadings untuk setiap pernyataannya, dan didapatkan semua angka $>0,5$ pada nilai Average Variance Extracted / AVE maka pernyataan yang digunakan sudah valid secara validitas konvergen. Selain itu, pada hasil validitas diskriminan, peneliti menggunakan nilai Cross Loadings dimana nilai korelasi antara pernyataan terhadap variabel nya sendiri harus lebih besar daripada pernyataan terhadap variabel lainnya berdasarkan hasil kalkulasi SmartPLS 3, didapatkan semua angka pada pernyataan terhadap variabel-nya sendiri lebih besar daripada terhadap variabel lainnya maka pernyataan sudah valid secara validitas diskriminan.

\section{Hasil Uji reliabilitas}

Pada hasil reliabilitas, maka berdasarkan hasil yang dikalkulasi oleh program SmartPLS 3, didapatkan semua angka pada nilai Cronbach's Alpha untuk setiap pernyataannya adalah > 0,7 dan pada nilai Composite Reliability didapatkan semua angka untuk setiap pernyataannya adalah > 0,7. Maka pernyataan yang digunakan dalam penelitian ini sudah reliabel berdasarkan kedua nilai reliabilitas, yakni Cronbach's Alpha dan Composite Reliability.

\section{Hasil Uji R-Square $\left(\mathbf{R}^{2}\right)$ dan GoF (Goodness of Fit)}

Dapat diketahui nilai $R$-Square untuk variabel kinerja adalah 0,592. Perolehan nilai tersebut menjelaskan bahwa sebesar 59.2\% variasi kinerja usaha dapat dijelaskan oleh variasi inovasi, proaktif, pengambilan risiko dan jaringan usaha. Sisanya sebesar 40,8\% dijelaskan oleh variabel lain 
Hasil uji GoF, didapatkan nilai GoF sebesar 0,661 yang berarti bahwa keseluruhan dalam kinerja model prediksi yang ditinjau pada tingkat kesesuaian antara inner model dengan outer model adalah besar karena di atas 0,36.

\section{Hasil Uji Hipotesis}

\section{Tabel 1}

Hasil Uji Hipotesis (Bootstrapping)

\begin{tabular}{|l|c|c|c|c|c|}
\hline & $\begin{array}{c}\text { Original } \\
\text { Sample } \\
(\mathrm{O})\end{array}$ & $\begin{array}{c}\text { Sample } \\
\text { Mean } \\
(\mathrm{M})\end{array}$ & $\begin{array}{c}\text { Standard } \\
\text { Deviation } \\
(\mathrm{STDEV})\end{array}$ & $\begin{array}{c}\text { T Statistics } \\
([\text { OSTDEV] })\end{array}$ & P Values \\
\hline $\begin{array}{l}\text { Inovasi } \rightarrow \text { kinerja } \\
\text { Usaha }\end{array}$ & 0.252 & 0.239 & 0.083 & 3.049 & 0.002 \\
\hline $\begin{array}{l}\text { Proaktif } \rightarrow \text { kinerja } \\
\text { Usaha }\end{array}$ & 0.276 & 0.288 & 0.076 & 3.633 & 0.000 \\
\hline $\begin{array}{l}\text { Pengambilan Risiko } \\
\rightarrow \text { Kinerja Usaha }\end{array}$ & 0.369 & 0.376 & 0.117 & 3.150 & 0.002 \\
\hline $\begin{array}{l}\text { Jaringan Kinerja } \\
\text { Usaha }\end{array}$ & 0.141 & 0.142 & 0.068 & 2.066 & 0.039 \\
\hline
\end{tabular}

\section{DISKUSI}

Hipotesis yang pertama menunjukkan bahwa variabel inovasi terbukti berpengaruh positif secara signifikan terhadap kinerja usaha karena hasil dari nilai t-statistik inovasi sebesar 3,049 yang berarti lebih besar dari 1,96 dan p-values sebesar 0,002 yang berarti lebih kecil dari 0,05 . Sehingga dapat disimpulkan bahwa inovasi memiliki pengaruh positif yang signifikan terhadap kinerja usaha. Hasil ini sesuai dengan penelitian Hendriyanto (2015) dan Yoon, et al (2018) yang menyatakan bahwa inovasi berpengaruh signifikan terhadap kinerja usaha. Inovasi secara luas dianggap sebagai salah satu sumber terpenting dari keunggulan kompetitif berkelanjutan dalam lingkungan yang semakin berubah, karena mengarah pada peningkatan produk dan proses, membuat kemajuan berkelanjutan yang membantu perusahaan untuk bertahan hidup, memungkinkan perusahaan tumbuh lebih cepat, lebih efisien, dan pada akhirnya menjadi lebih menguntungkan daripada non-inovator. Inovasi merupakan salah satu aspek penentu terhadap kinerja perusahaan, apalagi dalam lingkungan persaingan yang semakin ketat saat ini. Perusahaan yang mampu berinovasi akan memungkinkannya tetap bertahan dalam persaingan dan memperoleh keuntungan. Peningkatan laba yang diterima oleh perusahaan akan meningkatkan kinerja perusahaan. Inovasi merupakan pendorong pertumbuhan perusahaan, mengarahkan keberhasilan di masa depan dan penggerak perusahaan untuk tetap bertahan dalam lingkungan yang selalu berubah. Hal ini menunjukkan bahw ainovasi merupakan hal yang penting bagi setiap perusahaan.

Hipotesis kedua menunjukkan bahwa variabel proaktif berpengaruh positif signifikan terhadap kinerja usaha UKM di Jakarta Barat. Hasil ini sesuai dengan penelitian Yoon, et al (2018) menyimpulkanbahwa perilaku proaktif seorang pengusaha akan meningkatkan kinerja usaha yang di jalankannya. Demikian juga dengan penelitianyang dilakukan Arshad, et al (2014) menyatakan bahwa proaktif berpengaruh signifikan terhadap kinerja usaha. Peran dari sikap proaktif diantaranya seperti aktif dalam melakukan promosi untuk memasarkan produk, dapat menyusun strategi agar keuntungan dan output produk yang dipasarkan memenuhi target. Kecenderungan dalam menjalankan usahanya dengan mengambil sikap terhadap suatu masalah, yaitu bila masalah yang muncul akan disikapi, bukan untuk dihindari. Keaktifan 
(proactiveness) adalah sebuah pencarian peluang, perspektif memandang ke depan yang ditandai dengan pengenalan produk baru atau jasa baru lebih dulu dalam persaingan dan bertindak dalam mengantisipasi permintaan masa mendatang.

Hipotesis ketiga menunjukkan bahwa variabel pengambilan risiko berpengaruh positif signifikan terhadap kinerja usaha UKM di Jakarta Barat. Hasil ini sesuai dengan penelitian Yoon, et al (2018) menyatakan bahwa kecenderungan mengambil risiko berpengaruh signifikan terhadap kinerja usaha. Demikian juga dengan penelitian yang dilakukan oleh Arshad, et al (2014) serta penelitian Hapsari dan Setiawan (2019) menyimpulkan bahwa kecenderungan mengambil risiko berpengaruh terhadap kinerja usaha. Untuk mencapai sebuah kesuksesan tentu saja ada risiko yang harus dihadapi. Begitu juga dengan berwirausaha, ketika seseorang memutuskan untuk berwirausaha maka harus siap terhadap risiko yang akan dihadapi. Hal ini menunjukkan bahwa semakin mendekati puncak kesuksesan maka semakin besar pula risiko yang harus dihadapi. Wirausaha yang tidak takut terhadap risiko maka semakin besar pula kesuksesan yang akan didapat. Seorang wirausaha harus berani menghadapi risiko. Semakin besar risiko yang dihadapinya, semakin besar pula kesempatan untuk meraih keuntungan. Wirausaha yang sukses dinilai dari keinginannya untuk mulai bermimpi dan berani menanggung risiko dalam upaya mewujudkannya Umumnya resiko yang tinggi akan menghasilkan pengembalian yang tinggi sehingga seringkali pengambilan resiko dihubungkan dengan kesuksesan bisnis. Semakin berani pengusaha dalam mengambil resiko maka semakin tinggi kemungkinan sukses usahanya.

Hipotesis keempat menunjukkan bahwa variabel jaringan usaha berpengaruh positif signifikan terhadap kinerja usaha UKM di Jakarta Barat. Hasil ini sesuai dengan penelitian Yoon et, al (2018), menyatakan bahwa jaringan usaha berpengaruh positif terhadap Kinerja usaha. Hasil ini memberi makna bahwa informasi dan pengetahuan mempercepat pemahaman yang lebih baik mengenai pengembangan hubungan yang kuat dan flexibel dengan para pelanggan, dan juga dengan anggota-anggota rantai pemasok yang lain. Hubungan yang lebih dekat dengan pemasok akan memberikan kontribusi yang cukup kuat terhadap kinerja perusahaan, antara lain efisiensi biaya, peningkatan kualitas, reliabilitas,dan pemenuhan kebutuhan input yang selalu tersedia setiap saat. Selain itu pemasok dapat meningkatkan sumber informasi tentang pengembangan pasar, teknologi baru, pergerakan para pesaing. Pengusaha sukses menyadari pentingnya jaringan dalam proses memulai sebuah perusahaan baru. Jaringan usaha berguna untuk mengaktifkan pertumbuhan dan kelangsungan hidup usaha. Dengan adanya jaringan usaha membantu pengusaha untuk mengumpulkan informasi dan saran yang diperlukan dan selanjutnya berimbas pada peningkatan kinerja bisnis.

\section{KESIMPULAN}

Berdasarkan hasil analisis, maka dapat diambil beberapa kesimpulan sebagai berikut:

1. Inovasi berpengaruh positif signifikan terhadap kinerja usaha UKM di Jakarta Barat.

2. Proaktif berpengaruh positif signifikan terhadap kinerja usaha UKM di Jakarta Barat.

3. Pengambilan risiko berpengaruh positif signifikan terhadap kinerja usaha UKM di Jakarta Barat.

4. Jaringan usaha berpengaruh positif signifikan terhadap kinerja usaha UKM di Jakarta Barat.

Pada penelitian ini, memiliki beberapa keterbatasan yang diketahui yaitu sebagai berikut:

a. Penelitian ini hanya menggunakan empat variabel independen yaitu: inovasi, proaktif, pengambilan risiko, dan jaringan usaha yang dihubungkan secara langsung dengan satu dependen variabel yaitu: kinerja usaha. 
b. Penelitian ini hanya menggunakan sampel sebesar 100 responden karena adanya keterbatasan waktu dan keterbatasan kemampuan peneliti dalam mengambil sampel.

c. Cakupan wilayah pada penelitian ini kurang luas, hanya sebatas pada ruang lingkup di wilayah Jakarta Barat.

Pada penelitian ini saran yang akan diberikan kiranya dapat menjadi manfaat bagi perusahaan dan peneliti di masa mendatang.

1. Berdasarkan hasil analisis inovasi berpengaruh terhadap kinerja usaha, diharapkan perusahaan mampu mengembangkan produk yang mereka hasilkan. Produk sebaiknya dibuat lebih rapih, menarik dan jika memungkinkan dibuat sedemikian rupa sehingga memiliki keunikan tersendiri dibandingkan dengan produk pesaing. Inovasi pada produk dimaksudkan agar konsumen dapat dengan mudah mengenali produk sehingga produk memiliki tempat tersendiri di benak konsumen.

2. Bagi para pengusaha lebih giat mencari informasi mengenai peluang pasar lain yang masih berpotensi dan memanfaatkannya sebaik mungkin dan tidak mennyia-nyiakan peluang yang ada. Selain itu lebih aktif dalam menjemput peluang dan selalu mencari informasi terbaru mengenai kebutuhan konsumen. Selain mendatangi pelanggan, pemilik usaha bisa bersifat proaktif dengan cara mengikuti pameranpameran yang diadakan oleh instansi pemerintah maupun swasta.

3. Bagi para pengusaha diharapkan berani mengambil risiko atau meningkatkan kualitas produk yang dibuatnya dengan mengikuti trend jaman sekarang sehingga akan memberikan kepuasan lebih tinggi bagi konsumen yang akan membeli. Seorang wirausaha harus berani menghadapi risiko. Semakin besar risiko yang dihadapinya, semakin besar pula kesempatan untuk meraih keuntungan.

4. Pengusaha diharapkan mampu meningkatkan kerjasama dengan para pemasok dan pihak perantara, tidak hanya pemasok bahan baku. Hal tersebut bisa dilakukan dengan cara menjalin kerjasama yang baru dengan lebih banyak pemasok dan perantara. Sehingga pelaku UMKM memiliki kesempatan yang lebih besar untuk memilihbahan baku dan bahan penolong dengan harga yang terjangkau dan kualitas yang baik sertamemiliki kesempatan untuk meningkatkan penjualan produk.

\section{DAFTAR PUSTAKA}

Arshad, Azlin Shafinaz, Amran Rasli, Afiza Azura Arshad, dan Zahariah Mohd Zain (2014) The Impact of Entrepreneurial Orientation on Business Performance: A Study of Technology-based SMEs in Malaysia.

Edison, Emron (2016). Manajemen Sumber Daya Manusia Cetakan ke-1.Bandung:Alfabeta

Enny Susilowati M. dan Guruh Taufan. (2013). Pengembangan Jejaring Wirausaha dan Pembelajaran Eksploratif Sebagai Upaya Meningkatkan Kinerja Perekonomian Unit Usaha Kecil Menengah di Semarang. Jurnal Emba. Vol.2 No.3. Hal.1-15

Gunday, G., Alpkan, L., Bulut, C., Ulusoy, G., \& Kilic, K. (2009). Organizational support for intrapreneurship and its interaction with human capital to enhance innovative performance. Management Decision. 48 (5): 732-755.

Hapsari, Nurmalita Rhizky dan Setiawan, Achma Hendra (2019) Analisis Orientasi Kewirausahaan Terhadap Kinerja Usaha Industri Kreatif Bidang Kerajinan Di Kota Semarang. Diponegoro Journal Of Economics. Vol 1, No 1, hal. 47-54.

Haryo Santoso dan Yengky Imam Susanto (2014) Faktor-Faktor Yang Berpengaruh Terhadap Kewirausahaan Di Klaster Industri Mebel Kabupaten Blora. Journal of Industrial Engineering Management. Volume : Vol 9, No.1: 1-10 
Hendriyanto, Asepta (2015) Analisis Pengaruh Jaringan Usaha Dan Inovasi Terhadap Kinerja UMKM. Jurnal Ilmu Manajemen dan Akuntansi Terapan (JIMAT). Vol 6. No 1, hal. 45-50

Karimi, Saeid; Biemans, Harm J.A.; Lans, Thomas; Mulder, Martin; \& Chizari, Mohammad. (2011) Application of Structural Equation Modelling to Assess the effect of Entrepreneurial Characteristics on Students' Entrepreneurial Intentions. SSRN Electronic Journal. Vol. 5 (3) Hal. 1-15

Kotler, Philip dan Armstrong, Garry, (2008). Prinsip-prinsip Pemasaran, Jilid 1, Erlangga, Jakarta

Kreiser, Marino, dan Weaver (2015). Correlates of Entrepreneurship: The Impact of National Culture on Risk-taking Proactiveness in SMEs. Academy of Management Journal, 51(1), 97-111.

Lestari, Citra, Nawazirul Lubis dan Widayanto (2015)Pengaruh Jaringan Usaha, Inovasi Produk Dan Persaingan Usaha Terhadap Perkembangan Usaha Mikro, Kecil Dan Menengah (Studi pada IKM Makanan di Kecamatan Kuningan Kabupaten Kuningan Jawa Barat). Jurnal Anorag, Vol.1 No.1, hal 1-12

Mulyadi. (2010). Sistem Akuntansi. Jakarta: Salemba Empat

Nurlaila, (2010). Manajemen Sumber Daya Manusia I. Ternate: Penerbit LepKhair

Sari (2012). Analisis Faktor-faktor Pengaruh Inovasi Produk yang Berdampak pada Keunggulan Bersaing UKM Makanan dan Minuman di Wilayah Harjamukti Kota Cirebon”. Jurnal Logika. 18 (3) : $64-65$.

Widodo. (2013). Model Peningkatan Kinerja UKM Berbasis Orientasi Entrepreneurs. Jurnal Dinamika Manajemen. Vol 4 No 2::1-15

Yoon, Junghyun, Ki Keun Kim, and Alisher Tohirovich Dedahanov (2018) The Role of International Entrepreneurial Orientation in Successful Internationalization from the Network Capability Perspective. Sustainability. 1 (1): 1-14

Yuni, Siswanti (2011) Pengaruh Kepribadian Proaktif Terhadap Kesuksesan Karier Dengan Political Influence Behavior Sebagai Variabel Pemediasi. Prosiding dalam rangkaian Seminar Internasional Dan Call For Papers "Towards Excellent Small Business". h.71-93

Zimmerer, Thomas, Norman Scarborough (2008). Kewirausahaan dan Manajemen Usaha Kecil. Jakarta: Salemba Empat. 